\title{
THE SEC AND FOREIGN COMPANIES-A BALANCE OF COMPETING INTERESTS
}

\author{
Kenneth B. Davis, Jr. ${ }^{*}$
}

\section{INTRODUCTION}

This Article examines the rules governing foreign companies that seek to raise capital from U.S. investors or have their securities traded in the U.S. markets. This may seem too remote a corner of securities law's realm for a general conference on the SEC's "past, present, and future." Bear in mind, however, that this otherwise remote corner gave rise to the most visible and vigorous policy debate over the basic orientation and direction of U.S. securities law in the months preceding the recent financial crisis: the debate over whether the strictness of U.S. regulation caused our capital markets to lose some of their competitive advantage. ${ }^{1}$

The crisis may in turn contribute to competitiveness fears in its own way - by tarnishing the global image of the effectiveness of U.S. regulation. Whether or not this happens, it remains a safe bet that the momentum of globalization will continue to encourage both 1 ) the allocation of an increasing share of U.S. investor holdings to other parts of the world and 2) the growth, liquidity, and openness of foreign securities markets, and with it the role of those who regulate them. As a result, the SEC will likely find that considerations of harmony with what the rest of the world is doing will play a much greater role in shaping its policy agenda. Over the years ahead, the themes of this paper may therefore represent a rare source of deregulatory pressure in an otherwise re-regulatory environment.

* Dean, Fred W. \& Vi Moore Endowed Deanship, University of Wisconsin Law School.

1. See Comm'n on the Regulation of U.S. Capital Mkts. in the 21st Century, Report and Recommendations (Mar. 2007), available at http://www.uschamber.com/NR/rdonlyres/ eozwwssf rqzdm3hd5siogqhp6h2ngxwdpr77qw2bogptzvi5weu6mmi4plfq6xic7kjonfpg4q2bpks6ryog5wwh5sc/0 703capmarkets_full.pdf; Comm. on Capital Mkts. Regulation, The Competitive Position of the U.S. Public Equity Market (Dec. 4, 2007) [hereinafter CCMR Competitive Position Report], available at http:// www.capmktsreg.org/pdfs/The_Competitive_Position_of_the_US_Public_Equity_Market.pdf; CoMM. ON CAPital Mkts. Regulation, Interim Report of the Comm. on CAPital Mkts. Regulation (Nov. 30, 2006), available at http://www.capmktsreg.org/pdfs/11.30Committee_Interim_ReportREV2.pdf; Sustaining New York's and the US's Global Financial Services Leadership (2007), available at http://www.ci.nyc.ny.us/html/om/pdf/ny_report_final.pdf. 
Because some of the law in this area may be unfamiliar even to the securities regulation generalist, Sections II and III provide a basic background on the regulation of the various ways in which foreign companies raise capital from U.S. investors (Section II) and the U.S. trading of those companies' securities (Section III). With a view to the competitiveness debate, these sections will also consider how the level and means of foreign access to the U.S. capital markets has changed in recent years. Section IV then addresses the future. As a construct for identifying some of the issues that the SEC will face in the years ahead, and how those issues might be resolved, this section separately considers the (often conflicting) interests of the three U.S. groups with the biggest stakes in the outcome-issuers, investors, and the financial services industry. Section V contains a brief conclusion.

\section{RAISING CAPITAL FRom U.S. InVESTORS}

Foreign companies raise capital from U.S. investors in three basic transactional settings - within the United States, both publicly and privately, and outside the United States. This section briefly surveys the SEC's approach to each.

\section{A. Registered Public Offerings under the 1933 Act}

The registration requirements of section 5 of the 1933 Act apply to U.S. securities offerings by domestic and foreign issuers alike. ${ }^{2}$ While Schedule B of the Act details special disclosure requirements for offerings by foreign governments, no comparable accommodation was initially made for foreign private firms, perhaps because the volume of offerings by such firms was too small to warrant attention. ${ }^{3}$ Moreover, the SEC's position has been that the legislative history of the 1933 Act indicated an intent to treat foreign private issuers the same as their domestic counterparts. ${ }^{4}$ This absence of a formal distinction notwithstanding, the SEC staff would on occasion tolerate departures from U.S. accounting and auditing practices by foreign issuers

2. 1933 Act $\S 5,15$ U.S.C. $\S 77$ e (2006) (stating that the jurisdictional requirement of "interstate commerce" specifically includes trade or commerce between a foreign country and the US as well as between the individual states). See § 2(a)(7), 15 U.S.C. § 77b(a)(7).

3. See Louis Loss et al., Securities Regulation 679 (4th ed. 2007).

4. Integrated Disclosure System for Foreign Private Issuers, Securities Act Release No. 6360, Exchange Act Release No. 18274, 46 Fed. Reg. 58511, 58513 \& n.19 (Dec. 2, 1981). 
registering offerings under the 1933 Act. ${ }^{5}$ Overall, however, disclosure policy in the offering context contrasted sharply with the trading-market context where both (1) registration and annual reporting forms governing foreign issuers required "substantially less information" than their domestic counterparts, ${ }^{6}$ and (2) upon extending 1934 Act reporting requirements to firms traded over the counter, Congress expressly recognized the need to exempt at least some foreign securities.

This basic scheme was substantially revised beginning in the late 1970s. The SEC first proposed reducing the disclosure gap between domestic and foreign 1934 Act reporting companies, both to better protect U.S. investors and to address the competitive disadvantage incurred by U.S. firms. ${ }^{8}$ Foreign issuers of securities actively traded in the United States were thus required to provide more comprehensive annual reports, on present Form 20-F. Next, the Commission used that expanded annual report as the basis for a system of "integrated disclosure," parallel to the one it had developed for domestic companies. For the first time, a special set of 1933 Act disclosure requirements (currently Forms F-1 and F-3) was available to foreign issuers. Because the content of those forms was coordinated with the 20-F annual report, foreign issuers contemplating a public offering in the United States could now take advantage of at least some of the disclosure accommodations that the SEC had accepted in response to the criticism generated by its original $20-\mathrm{F}$ proposal. Thus, in recognition of the international differences in disclosure law, practice, and custom, foreign issuers had been spared the need to annually report such items as the profits of each separate business segment and the compensation of senior executives, ${ }^{9}$ with the latter accommodation extended to the public offering context as well.

Eligibility for these reduced disclosure obligations turns, then as now, on the issuer's status as a "foreign private issuer"- a defined term that looks not

5. Loss, supra note 3, at $681 \mathrm{n} .48$.

6. See Means of Improving Disclosure by Certain Foreign Private Issuers, Exchange Act Release No. 13056, 41 Fed. Reg. 55012, 55013 (Dec. 16, 1976).

7. 1934 Act $\S 12(\mathrm{~g})(3), 15$ U.S.C. $\$ 781(\mathrm{~g})(3)(2006)$.

8. Foreign Private Issuers, Exchange Act Release No. 14128, 42 Fed. Reg. 58684-85 (Nov. 10, 1977).

9. Rules, Registration and Annual Report Form for Foreign Private Issuers, Exchange Act Release No. 16371, 44 Fed. Reg. 70132, 70134 (Dec. 6, 1979). The accommodation as to segment data was ultimately eliminated in 2008. See Foreign Issuer Reporting Enhancements, Securities Act No. 8959, Exchange Act Release No. 58620, 73 Fed. Reg. 58300 (Oct. 6, 2008). 
only to the issuer's place of incorporation, but also requires that a majority of its shareholders and business be located outside of the United States. ${ }^{10}$

The SEC saw these accommodations as the product of its need to "evaluate two competing policies." 11

\begin{abstract}
One is the recognition that the investing public in the United States needs the same type of basic information disclosed for an investment decision regardless of whether the issuer is foreign or domestic. This view suggests that foreign registrants be subject to exactly the same requirements as domestic ones. The other is that the interests of the public are served by an opportunity to invest in a variety of securities, including foreign securities. This policy implies that the imposition on foreign issuers of the same disclosure standards applicable to domestic issuers could discourage offerings of foreign securities in the United States, thereby depriving United States investors of the opportunity to invest in foreign securities. According to this reasoning, the public interest would be best served by encouraging foreign issuers to register their securities with the Commission. ${ }^{12}$
\end{abstract}

Just how immediately effective the new integrated disclosure system was in providing the necessary encouragement is not altogether clear, in part because of the problem of finding consistent data over time. In 1983, the year following adoption of the new rules, the volume of debt and equity offerings by foreign issuers was $\$ 2.6$ billion, double the year before, but still at roughly the same level as 1980, suggesting that the 1983 jump might be due more to market conditions than regulatory encouragement. ${ }^{13}$ By 1992 , however, when data on 1933 Act filings by foreign issuers was first included in the SEC's Annual Report, the annual volume of registered foreign offerings had reached $\$ 34.6$ billion $^{14}$ and continued to grow steadily through the ensuing decade.

10. 1933 Act Rule 405,17 C.F.R. $\S 230.405$ (2009) ("The term foreign private issuer means any foreign issuer other than a foreign government except an issuer meeting the following conditions as of the last business day of its most recently completed second fiscal quarter: (i) More than $50 \%$ of the outstanding voting securities of such issuer are directly or indirectly owned of record by residents of the United States; and (ii) Any of the following: (A) The majority of the executive officers or directors are United States citizens or residents; (B) More than $50 \%$ of the assets of the issuer are located in the United States; or (C) The business of the issuer is administered principally in the United States.").

11. Integrated Disclosure System for Foreign Private Issuers, supra note 4, at 58513.

12. $I d$.

13. Supporting a more market-based explanation is the fact that foreign company offerings represented only $1.4 \%$ of registered offerings in the four years following adoption (1983-1986), compared to $2.3 \%$ in the four years preceding it (1978-1981). Internationalization of the Securities Markets, SEC Staff Report to Senate Comm. on Banking, Housing \& Urban Affairs and House Comm. on Energy \& Commerce, at II-105 tbl.II-O (July 27, 1987).

14. 1992 SECANN.REP. 52 (1992), available at $\mathrm{http}: / / \mathrm{www}$. sec.gov/about/annual_report/1992.pdf (last visited Feb. 16, 2010). The SEC ceased reporting detailed break downs on the amount of 1933 Act registrations in early 1989. See Table M-370, Gross Proceeds from Primary Public Offerings by Industry: 
Over the last decade, the SEC has made substantial strides in harmonizing the U.S. disclosure requirements applicable to foreign private issuers with emerging global norms. Thus, in 1999 it replaced the nonfinancial information requirements of the 20-F annual report with those adopted by the International Organization of Securities Commissions ("IOSCO"). ${ }^{15}$ And beginning in 2007, it permitted foreign private issuers to prepare their financial statements in accordance with International Financial Reporting Standards, without the requirement that they be reconciled with U.S. GAAP. ${ }^{16}$ To the extent that the U.S. public capital markets remain an attractive option for foreign companies, the willingness to make these kinds of accommodations, in addition to promoting global convergence, significantly strengthen the SEC's hand in shaping what the resulting norms will be. ${ }^{17}$

This spirit of accommodation stands in sharp contrast with Congress' failure to draw any distinction between domestic and foreign issuers in the Sarbanes-Oxley Act of $2002 .{ }^{18}$ While the SEC has made some effort to temper the Act's application to foreign private issuers, ${ }^{19}$ its authority to do so is quite limited. Consequently, compliance with Sarbanes-Oxley remains a serious concern for foreign companies contemplating offerings or listing in the United States.

Important questions therefore exist about the ongoing viability of the registered public offering as a means for foreign companies to raise capital in the United States. From the 1992 level of \$34.6 billion cited above, the annual

1985-1988, SEC Monthly Statistical Review, 48, \#2 (Feb. 1989).

15. International Disclosure Standards, Securities Act Release No. 7745, Exchange Act Release No. 41936, 64 Fed. Reg. 53900, 53900 (Oct. 5, 1999).

16. Acceptance from Foreign Private Issuers of Financial Statements Prepared in Accordance with International Financial Reporting Standards without Reconciliation to U.S. GAAP, Securities Act Release No. 8879, Exchange Act Release No. 57026, 73 Fed. Reg. 986, 986 (Jan. 4, 2008).

17. Cf. James D. Cox, Coping in a Global Marketplace: Survival Strategies for a 75-Year-Old SEC, 95 VA. L. REV. 941, 985-87 (2009) (evaluating SEC's optimal strategy for dealing with the International Accounting Standards Board).

18. Pub. L. No. 107-204, 116 Stat. 745 (2002). Little in Sarbanes-Oxley's legislative history suggests that Congress ever seriously considered the special status of foreign private issuers. See Michael A. Perino, American Corporate Reform Abroad: Sarbanes-Oxley and the Foreign Private Issuer, 4 EUR. Bus. Org. L. Rev. 213, 221-23 (2003). But cf. Roberta S. Karmel, The Securities and Exchange Commission Goes Abroad to Regulate Corporate Governance, 33 Stetson L. REV. 849, 862-63 (2004) (stating that Sarbanes-Oxley's application to foreign issuers is consistent with SEC's subtle shift in the direction of greater "unilateralism").

19. See, e.g., Management's Report on Internal Control over Financial Reporting and Certification of Disclosure in Exchange Act Periodic Reports, Securities Act Release No. 8392, Exchange Act Release No. 49313, 69 Fed. Reg. 9722 (Mar. 1, 2004) (extending compliance date); Standards Relating to Listed Company Audit Committees, Securities Act Release No. 8220, Exchange Act Release No. 47654, 68 Fed. Reg. 18788, 18802-04 (Apr. 16, 2003). 
volume of registered foreign debt and equity offerings climbed steadily, according to the SEC's Annual Reports, to a high of \$267 billion in fiscal year $2001 .^{20}$ In the years thereafter, however, new registrations fell to an annual average of 155 billion. ${ }^{21}$ The recent reports of the Committee on Capital Markets Regulation (CCMR) portray an even more dramatic fall off. Using Dealogic data, they compile the volume of "Global IPOs" (IPOs by foreign companies listed on at least one exchange outside the issuer's country of domicile) listed on a U.S. exchange. That amount peaked at $\$ 35.3$ billion in 2000 , but has averaged only $\$ 6.7$ billion in subsequent years. ${ }^{22}$

While this sharp downward trend in foreign registered offerings is clear, the reasons for it are not. One hypothesis, favored by those who fear the flagging competitiveness of U.S. capital markets, is that foreign issuers are deterred by recent development that increase both the burden and risk posed by U.S. securities law. In addition to Sarbanes-Oxley, they cite the threat of securities class actions, which have been brought against foreign companies at an increasing rate. ${ }^{23}$ On the other hand, the trend is also no doubt due to the increased depth and liquidity of foreign securities markets as well as to the subject to which we now turn - the alternative of a private U.S. offering. ${ }^{24}$

20. 2001 SECANN. REP. 77 (2001), available at http://www.sec.gov/pdf/annrep01/ar01full.pdf(last visited Feb. 16, 2010).

21. Again, there is a question of data comparability. For the years 1992-2002, the Annual Report referred to the amount of public offerings filed. With the 2004 change in the report's format, the description changed to the dollar amount of securities registered under the 1933 and 1934 Acts. While these are two different concepts, the data that bridge both formats are the same. See SEC, 2004 Performance \& Accountability Report 62 fig 2.7, available at http://www.sec.gov/about/secpar/secpar04.pdf. To the extent, however, that the latter data does include 1934 Act registrations of securities not registered under the 1933 Act, the fall of in the level of registered offerings becomes even steeper.

22. Comm. on Capital Mkts. Regulation, Share of Global IPOs (Narrowly Defined) Captured by U.S. Exchanges, http://www.capmktsreg.org/competitiveness/2009Q2update/(2A)Share_of_Global_IPOs Captured_by_US_Exchanges(narrow).pdf. (last visited Nov. 14, 2009) The CCMR data reported throughout this paper are taken from the quarterly updates to the various competitiveness measures originally published in the CCMR Competitive Position Report, supra note 1.

23. Over the period from 1997 to mid-2009, the percentage of overall class actions brought against companies headquartered outside the United States has steadily increased, even as the number of those companies listed in the U.S. markets has declined. See Cornerstone Research, Securities Class Action Filings-2009 Mid-Year Assessment 7 \& fig. 6 (2009), available at http://securities.cornerstone.com/ pdfs/2009_Mid-Year_Assessment.pdf.

24. See, e.g., Howell E. Jackson \& Eric J. Pan, Regulatory Competition in International Securities Markets: Evidence from Europe-Part II, 3 VA. L. \& BUS. Rev. 207, 210 (2008) (finding that, by the late 1990 s, European issuers had already begun to turn away from the U.S. public capital markets). 


\section{B. Offerings to Qualified Institutional Buyers under Rule 144A}

Rule $144 \mathrm{~A}$ is a testament to the SEC's creativity in finding ways to respond to the evolution of the financial marketplace within the confines of seventy-five-year old statutory framework. The logic underlying the Rule is without fault: Very large institutional investors should be permitted to choose whether they require the protections afforded by 1933 Act registration. Lacking an express statutory window to attain that result, the Commission cobbled one together from concepts developed over the years under two of the 1933 Act's most important exemptions - the section 4(1) exemption for transactions not involving an issuer, underwriter or dealer, and the section 4(2) private offering exemption. Specifically, sales pursuant to Rule 144A are declared not to constitute a "distribution," with the result that purchases of securities from the issuer with a view to reselling them under the Rule does not have the effect of negating either the issuer's or reseller's exemption from registration. ${ }^{25}$

Eligibility for the Rule 144A exemption entails three conditions. First, offers and sales may be made only to persons reasonably believed to meet the definition of "qualified institutional buyer" ("QIB")—generally traditional institutional investors with $\$ 100$ million or more in assets under management. ${ }^{26}$ Second, the securities being sold cannot be of the same class as listed on a U.S. national exchange or traded in a U.S. national quotation system. ${ }^{27}$ This requirement - that the securities be "non-fungible"-was included to prevent the risk of a side-by-side 144A market that might undermine the liquidity and efficiency of the existing public market for the issuer's securities. ${ }^{28}$ Listing on a foreign exchange, in contrast, poses no comparable impediment to the availability of Rule 144A. If, however, the foreign issuer were to cross-list those securities in the United States, it could no longer take advantage of Rule 144A for offerings of the same class. ${ }^{29}$ (2009).

25. See Private Resales of Securities to Institutions, 17 C.F.R. $\S 230.144$ A(b), (c), prelim. note 7

26. 17 C.F.R. $\S 230.144 \mathrm{~A}(\mathrm{a})(1)(\mathrm{i}),(\mathrm{d})(1)$.

27. 17 C.F.R. $\S 230.144 \mathrm{~A}(\mathrm{~d})(3)$.

28. Resale of Restricted Securities International Series-104, Securities Act Release No. 6839, 54 Fed. Reg. 30076, 30077-78, 30081 (July 18, 1989).

29. Even though the U.S.-listed securities are in the form of ADRs (see infra Section III.A), they would foreclose a $144 \mathrm{~A}$ offering of the deposited securities - that is, the ordinary securities traded in the issuer's home market - as well. See Resale of Restricted Securities; Changes to Method of Determining Holding Period of Restricted Securities under Rules 144 and 145, Securities Act Release No. 6862, 55 Fed. Reg. 17933, 17935 (Apr. 30, 1990). 
Finally, unless the issuer is either subject to the 1934 Act's reporting requirements or exempt from those requirements under rule 12g3-2(b) (see Section III.B below), it must provide investors, upon request, a brief description of its business and its most recent financial statements. ${ }^{30}$

Securities acquired pursuant to Rule 144A have the status of Rule 144 "restricted securities" in the hands of the QIB. ${ }^{31}$ Two important possibilities for immediate resale exist, however, so that Rule 144A securities enjoy greater liquidity than other types of restricted securities, particularly for foreign issuers. First, the securities can be sold to dealers for resale to other QIBs under Rule 144A. Alternatively, the securities may be sold in offshore transactions in the issuer's home market (or other global markets) under Regulation S, discussed in the next subsection, or exchanged for the issuer's publicly marketable securities in so-called Exxon Capital transactions. ${ }^{32}$

In proposing Rule 144A, the SEC clearly had in mind the opportunity for foreign companies to use this new exemption as an attractive means of entering the U.S. capital markets:

The Rule may have significant implications for offerings by foreign issuers. Foreign issuers who previously may have foregone raising capital in the United States due to the compliance costs and liability exposure associated with registered public offerings, and the costs of financing inherent in placing restricted securities, may find private placements in the United States a more viable capital-raising option as a result of the combined effect of proposed Rule 144A and proposed Regulation S. Greater participation by foreign issuers in the U.S. capital market also would have the benefit of reducing the costs borne by U.S. institutional investors that wish to invest in foreign securities and are compelled at present to go overseas to obtain such securities. Moreover, U.S. intermediaries who may have lost business to foreign competitors simply because such securities may be available only offshore may be afforded more opportunities to participate in the internationalization of investment strategies. $^{33}$

30. Rule 230.144A(d)(4). In light of the possible duty to update any information furnished under this requirement, one leading authority has suggested that eligible foreign private issuers give serious consideration to availing themselves of the rule 12g3-2(b) exemption, discussed below in Section III.B. Edward F. Greene et al., U.S. Regulation of the International Securities and Derivatives MARKeTS $\S 4.03[$ d] [ii] (9th ed. 2008).

31. Private Resales of Securities to Institutions, 17 C.F.R. $\S 230.144$ A prelim. note 6 (2009).

32. Exxon Capital Holdings Corp., SEC No-action Letter, 1988 WL 234336 (May 13, 1988). Unlike domestic issuers, foreign issuers are allowed to use this procedure for equity as well as debt. See Robert G. DeLaMater, Recent Trends in SEC Regulation of Foreign Issuers: How the U.S. Regulatory Regime Is Affecting the United States' Historic Position as the World's Principal Capital Market, 39 CORNELL INT'L L.J. 109, 112-13 (2006).

33. Resale of Restricted Securities, Securities Act Release No. 6806, 53 Fed. Reg. 44016, 44022 (Nov. 1, 1988). 
Foreign private issuers have definitely taken advantage of the resulting opportunity. According to the CCMR, in 2007, the year before the recent financial crisis, foreign companies doing offerings that included the U.S. markets raised $\$ 94.8$ billion under Rule 144A—over 7 times the amount they raised through IPOs listed on a U.S. exchange. ${ }^{34}$ While the U.S. private placement market was historically a debt market, issuers had begun using it to raise equity capital even before the adoption of Rule $144 \mathrm{~A} .{ }^{35}$ For foreign issuers, Rule 144A has proven particularly advantageous for equity offerings. Using data from the Bank of New York Mellon's ADR ${ }^{36}$ program, the CCMR estimates that foreign companies raised an annual average of $\$ 3.8$ billion in equity through Rule 144A ADR offerings over the period from 2000 to 2008, with a high of $\$ 17$ billion in $2006 .{ }^{37}$

\section{Offshore Transactions}

What if the offer and sale of securities occurs outside the United States? Most of the law and lore in this area has developed in the context of sales by U.S. issuers in foreign markets. This combination is, of course, the direct opposite of offerings by foreign issuers to U.S. investors, the focus of this paper. Yet many of the concepts developed in the former context apply alike to foreign issuers, especially those with the existence or prospect of an investor following in the United States.

The overarching issue is the extent to which the protections of the U.S. securities laws follow U.S.-based investors into foreign capital markets. To be sure, if the transaction at issue contains no element of "interstate commerce," it will fall outside the jurisdictional sweep of section 5's registration requirements. ${ }^{38}$ But the prospect that negotiations and documentation could entail at least some communication back to the U.S. might understandably

34. Committee on Capital Markets Regulation, Rule 144A ipos by Foreign Companies as a Percentage of Total Global IPOS IN the U.S., http://www.capmktsreg.org/competitiveness/ 2009Q2update/(4)Rule_144A_IPOs_by_Foreign_Companies_as_a_Percentage_of_Total_Global_IPOs in_the_US.pdf.

35. Resale of Restricted Securities, supra note 33, 53 Fed. Reg. at 44016.

36. See ADRs (American Depositary Receipts) descriptions infra Section III.A.

37. Committee on Capital Markets Regulation, "Equity Raised by Foreign Issuers in the U.S. via Rule 144A ADRs as a Percentage of Equity Raised in the U.S. by Foreign Issuers in the Public Market," http://www.capmktsreg.org/competitiveness/2009Q2update/(7)Equity_Raised_by_Foreign_Issuers_Via _Rule_144A.pdf.

38. See supra note 2 . 
dissuade the foreign issuer from allowing U.S. investors to participate in a contemplated overseas offering.

The SEC addressed these questions in its 1964 Release 4708, during the early days of the Eurobond market through which multinational companies found it attractive to raise dollar-denominated debt capital abroad. The Commission noted that notwithstanding the literal reach of section 5, its traditional position was that registration under the 1933 Act was primarily intended to protect U.S. investors, and therefore it had not taken action when U.S. corporations distributed unregistered securities abroad to foreign nationals. It added, however, that this position assumed "that the distribution is to be effected in a manner which will result in the securities coming to rest abroad." ${ }^{39}$ Through no action letters in the years following the adoption of 4708, the SEC staff developed a system of "lock-up" arrangements - procedures to prevent securities initially placed offshore from flowing back to the U.S. market.

By the late 1980s, the dramatic growth of international financial markets led the SEC to revisit its approach to offshore offerings. The result was Regulation $\mathrm{S},{ }^{40}$ a safe harbor based on a "territorial approach," which sees the purpose of 1933 Act registration as protecting the U.S. capital markets and those investors (domestic and foreign) who purchase securities within them. ${ }^{41}$ The core prerequisites for the safe harbor are that the offer or sale be made in an "offshore transaction" and that no "directed selling efforts" be made in the United States. ${ }^{42}$ Both are elaborately defined terms, with "offshore transaction" of particular interest for our purposes. It requires (1) that the offer not be made in the U.S. and (2) that either (a) the buyer is, or is reasonably believed to be, outside the U.S. at the time of the buy order or (b) the transaction is executed on an established foreign securities exchange or designated offshore market. ${ }^{43}$ For purposes of determining the buyer's location, the SEC release adopting the safe harbor adds an important qualification for U.S.-based institutional investors and investment funds. Corporations and partnerships, including investment companies, will be

39. Registration of Foreign Offerings by Domestic Issuers; Registration of Underwriters of Foreign Offerings as Broker-Dealers, Securities Act Release No. 4708, 29 Fed. Reg. 9828 (July 14, 1964).

40. 17 C.F.R. $\S \S 230.901-.905$ (2009). 1988).

41. Offshore Offers and Sales, Securities Act Release No. 6779, 53 Fed. Reg. 22661, 22665 (June 7,

42. 17 C.F.R. $\S 230.903(a)$.

43. 17 C.F.R. $\S 230.902(h)(1)$. 
deemed outside the United States if an authorized employee places the buy order while abroad - no matter where the actual investment decision is made. ${ }^{44}$

Whether additional requirements or restrictions apply under Reg. S depends on the category of securities at issue. Offerings by foreign private issuers could fall into any of the regulation's three categories. Given the SEC's longstanding concern over securities that might flow back to the United States, the threshold question in determining which category applies is whether there is "substantial U.S. market interest" ("SUSMI") - a term separately defined for debt and equity ${ }^{45}$ - for the class of securities being offered. In the absence of SUSMI, the securities qualify for Category 1, and therefore no further restrictions apply. Further, even for foreign private issuers with SUSMI, "overseas directed offerings"- that is, offerings directed into a single country other than the United States, conducted under local law, custom and currency ${ }^{46}$ - fall under Category 1 as well.

Categories 2 and 3 , in contrast, impose restrictions on the period of time during which the securities cannot be offered or sold to a "U.S. person." The length of the time period depends upon the class of securities involved and the existing availability of U.S. information regarding the issuer. Specifically, under Category 2, applicable in the case of foreign private issuers to both debt securities and, if the issuer is a 1934 Act reporting company, equity securities as well, the relevant compliance period is forty days. ${ }^{47}$ For offerings of equity securities by foreign private issuers that do not file 1934 Act reports, the compliance period is a full year, under Category $3 .{ }^{48}$

Various mechanisms exist, however, for U.S. investors to participate in an offering of Category 2 or 3 securities, even during the restricted period. Generally speaking, the definition of "U.S. person" looks to who is making the investment decision, not who has the economic stake. ${ }^{49}$ Thus, discretionary accounts held by a foreign fiduciary fall outside the definition, even if the account is on behalf of a U.S. person. ${ }^{50}$ And for at least some U.S. investors, the definition of "U.S. person" affords latitude even when they retain investment authority. Specifically excluded from the definition of U.S. person are the foreign branches of U.S. banks and insurance companies, so long as

44. Offshore Offers and Sales, Securities Act Release No. 6863, 55 Fed. Reg. 18306, 18310 \& n.39 (May 2, 1990).

45. 17 C.F.R. $\S 230.902(j)$.

46. 17 C.F.R. $\S 230.903(b)(1)($ ii)(A).

47. 17 C.F.R. $\S 203.903(b)(2)$.

48. 17 C.F.R. $\S 230.903(b)(3)$.

49. See Offshore Offers and Sales, Securities Act Release No. 6863, supra note 44, at 18316-17.

50. See Securities Act of 1933, 17 C.F.R. § 230.902(k)(1)(vii) (by implication). 
they are operated for valid business reasons. ${ }^{51}$ The definition also indicates that a foreign partnership or corporation organized by a U.S. person for purposes of investing in unregistered securities will not itself be deemed a U.S. person, so long as the organizer and owner of the partnership or corporation is an accredited investor who is not a natural person, estate or trust. ${ }^{52}$ Finally, in order not to place U.S. money managers under a competitive disadvantage, the definition departs from the general rule described above and excludes any discretionary account (other than an estate or trust) held by a U.S. professional fiduciary, if the beneficiary is not a U.S. person. ${ }^{53}$

What limitations apply to the resale of foreign securities acquired by a U.S. investor in a Regulation S offering? Category 2 and 3 securities are subject to the forty-day or one-year restriction on offers or sales to U.S. persons. But by their terms, these restrictions apply only to offers or sales by issuers, "distributors" (underwriters, dealers and other participants in the distribution), their affiliates and those acting on their behalf. Further, Rule 905 was added to Reg. S in 1998 to provide that equity securities of domestic issuers subject to these restrictions have the status of "restricted securities" under Rule 144, but the SEC elected not to impose comparable treatment on foreign securities, as it had originally proposed. ${ }^{54}$

U.S. investors should therefore be mindful of the fact that Reg. S contains its own safe harbor for resales. As with Reg. S generally, it requires that the securities be offered and sold in offshore transactions, and that there be no directed selling efforts in the U.S. Importantly, the availability of this safe harbor is not confined to securities acquired in Reg. S transactions. ${ }^{55}$ Securities acquired in Reg. D offerings or other private placements, as well as under Rule 144A, can therefore also be resold under the safe harbor.

\section{A Note on Integration}

To be sure, the securities of foreign private issuers can generally be sold to U.S. investors under the other exemptions available to their domestic counterparts. Along with Rule 144A, private offerings under section 4(2) and limited offerings under Regulation D are the most obvious examples. The

51. 17 C.F.R. $\S 230.902(\mathrm{k})(2)(\mathrm{v})$.

52. 17 C.F.R. $\S 230.902(\mathrm{k})(1)($ viii).

53. 17 C.F.R. $\S 230.902(\mathrm{k})(2)(\mathrm{i})$.

54. Offshore Offers and Sales, Securities Act Release No. 7505, 63 Fed. Reg. 9632, 9633-34 (Feb 17, 1998).

55. See generally 1933 Act, supra note 2; 17 C.F.R. § 230.904(a). 
contemporaneous use of multiple exemptions to sell similar securities ordinarily creates the risk that the separate offerings might be integrated as one, with the consequence that one or more of the exemptions will be lost. Offshore offerings under Reg. S are treated differently, however. The SEC's position is that these offerings will not be integrated with U.S. registered or exempt offerings of the same securities, even when the two offerings are coincident. ${ }^{56}$ Thus, global offerings by foreign companies often consist of separate Regulation S and Rule 144A tranches.

\section{U.S. TRADING MARKETS}

\section{A. ADR Programs}

American Depositary Receipts (ADRs) are the principal format used for U.S. trading in the securities of foreign companies. Foreign shares are deposited with a U.S. commercial bank, which in turn issues the ADRs, each corresponding to a set number of the underlying shares. The ADRs then trade and settle in dollars. ADR programs may be either "sponsored"- that is, organized by the foreign issuer itself-or created without the issuer's participation ("unsponsored"). Beginning with Daimler Chrysler in 1998, the U.S. markets developed "global share" arrangements as an alternative to ADRs. Global shares trade in the same form in both the home and U.S. market.

ADR programs are often characterized in terms of "Levels." In a Level I program, the ADRs trade in the over the counter market. Level I programs may therefore be sponsored or unsponsored. Level II and III programs, in contrast, require the issuer's participation. Level II programs entail listing the ADRs on a U.S. exchange and therefore require registration under the 1934 Act, as discussed in the next subsection. Level III programs involve raising capital through a public offering, after which the ADRs are to be listed on an exchange. Level III programs therefore require registration under both the 1933 and 1934 Acts. $^{57}$

56. See, e.g., Regulation D, prelim. note 7, 17 C.F.R. $§ \S 230.501-.506$; Offshore Offers and Sales, Securities Act Release No. 6863, supra note 44, at 18320.

57. ADRs are also used for foreign securities offered under Rule 144A (sometimes referred to as a Level IV program) or Reg. S, and therefore subject to restrictions on resale. 


\section{B. 1934 Act Registration and Reporting}

The 1934 Act requires the registration of any securities that are actively traded in the U.S. markets. That registration serves as the triggering event for ongoing disclosure and reporting obligations as well as rules governing various corporate-shareholder matters such as proxy voting, tender offers and short-swing profits. Specifically, registration requirements apply to issuers in two situations. One is companies whose securities are traded on a U.S. national securities exchange.$^{58}$ For foreign private issuers, this is the principal source of the obligation to register. As of December 31, 2008, the SEC identified a total of 1024 companies as subject to the 1934 Act registration and reporting requirements. Of these, 458 were listed on the New York or American Stock Exchanges, while 248 were listed on the NASDAQ Global or Capital Markets. ${ }^{59}$

The alternative registration requirement applies to companies with assets in excess of $\$ 10$ million and a class of equity securities held of record by 500 or more persons. ${ }^{60}$ It is this second registration prong that creates the greater potential for undue hardship on foreign issuers. Foreign securities may, over time, find their way into the hands of U.S. investors without any attempt or desire on the issuer's part to access the U.S. capital markets. Even more daunting, the 500-person threshold is not by its terms limited to U.S. persons. To address these sorts of problems, Congress, as a part of the 1964 legislation extending the 1934 Act registration requirements to non-listed securities, granted the SEC broad authority to exempt the securities of foreign issuers. ${ }^{61}$

Pursuant to this authority, the SEC has created two important exemptions for foreign private issuers whose shares trade on an over-the-counter basis in the United States. The first exempts any class of securities with fewer than 300 holders resident in the United States. ${ }^{62}$ Second, under rule 12g3-2(b), even those foreign companies that exceed the 500-shareholder and 300-resident thresholds could qualify for exemption if, prior to 2008, they applied to the SEC and filed copies of any financial or other investment-related information

58. 15 U.S.C. $\S \S 78 l$ (a)-(b) (2006); Securities Exchange Act of 1934, ch. 404, $\S$ 12(a)-(b), 48 Stat. 881, 892-93 (1934). In addition, issuers that conduct a 1933 Act registered offering are required to file 1934 Act periodic reports, even if they are not required to register under section 12. 15 U.S.C. $\S 78 o(d)$; 17 C.F.R. $\S 240.15$ (d) (2009).

59. Securities and Exchange Commission, Foreign Markets Summary (2008), available at http://www.sec.gov/divisions/corpfin/internatl/foreignmarketsumm2008.pdf.

60. 15 U.S.C. $\S 78 l(\mathrm{~g})(1)(B)(2006) ; 17$ C.F.R. $\S 240.12(\mathrm{~g})(1)(2009)$.

61. 15 U.S.C. $\$ 78 l(\mathrm{~g})(3) ; 17$ C.F.R. $\$ 240.12(\mathrm{~g})(3)(2)$.

62. 17 C.F.R. $\S 240.12(\mathrm{~g})(3)(2)(\mathrm{a})$. 
that they file or make public in their home jurisdiction. ${ }^{63}$ As of June 2005, the SEC's most recent published listing, 672 foreign private issuers were claiming the exemption. ${ }^{64}$

In recognition of the increased globalization of the securities markets, the SEC substantially revised the terms of the second of these exemptions in 2008. As a result, the exemption is now limited to companies listed on one or more foreign exchanges that represent their primary trading market, but application to the SEC is no longer required. Instead, in order to maintain the exemption, the company must provide English translations of its principal disclosure documents (such as the annual report and financial statements) and make them available on its web site. ${ }^{65}$

Elimination of the application requirement has produced an explosion in the number of unsponsored ADR programs, because depositary banks no longer require the issuer's participation. The depositary is required only to have a reasonable, good faith belief, after exercising reasonable diligence, that the issuer satisfies the exemption's English language information requirements. ${ }^{66}$ As a result, the number of unsponsored ADR programs has climbed from 217 to 1044 since September 2008, according to the directory maintained by BNY Mellon. ${ }^{67}$

Finally, even if required to register under the 1934 Act, foreign private issuers are excepted from many of the obligations imposed on domestic companies. They are not required to file reports on a quarterly basis, and the 1934 Act rules governing proxy solicitations and short-swing profits do not apply. ${ }^{68}$ This longstanding pattern of relieving foreign private issuers from so many of the corporate governance components of the 1934 Act made Congress's 2002 decision to subject those issuers to Sarbanes-Oxley all the more striking.

63. 17 C.F.R. $\S 240.12(\mathrm{~g})(3)(2)(\mathrm{b})$.

64. Securities and Exchange Commission, List of Foreign Issuers That Have Submitted Information under the EXemption Relating to Foreign Securities, Release No. 34-51893 (June 21, 2005) available at http://sec.gov/rules/other/34-51893.pdf.

65. Exemption from Registration under Section 12(g) of the Securities Exchange Act of 1934 for Foreign Private Issuers, Exchange Act Release No. 58465, 73 Fed. Reg. 52752, 52753 (Sept. 5, 2008).

66. Id. at 52762; see also Shearman \& Sterling LLP, Understanding AND Dealing With UnsPonsored ADR Programs (Nov. 2008), available at http://www.shearman.com/files/upload/ Client_Publication_Unsponsored_ADR_Programs.pdf.

67. See generally BNY Mellon Depository Receipts Directory, http://www.adrbnymellon.com/ dr_directory.jsp.

68. 17 C.F.R. $\S 240.3(a)(12)(3)(b)$. 


\section{Delisting and Deregistration}

What if a foreign company wishes to exit the U.S. trading markets? This became a matter of heightened concern as foreign issuers confronted the prospect of compliance with the various demands of Sarbanes-Oxley.

Historically, the SEC has taken an asymmetric approach to the issues of entry and exit. Even if an issuer terminated the listing of its securities on a U.S. exchange, it continued to be subject to 1934 Act reporting requirements so long as that class of securities was held by 300 or more U.S. residents. Thus, even under circumstances in which a foreign private issuer would otherwise have been eligible for the 12g3-2(b) exemption discussed above, the fact of its previous listing required it to continue filing reports under the 1934 Act. Further, if the securities had been the subject of a 1933 Act registered offering, the issuer's reporting requirements were merely "suspended" when its resident shareholders fell below 300 , requiring the issuer to continually monitor that number into the future. By thus making exit difficult, the SEC assured prospective purchasers of the issuer's securities that they would have the benefits of mandatory disclosure on an ongoing basis. ${ }^{69}$

In 2005, recognizing that these obstacles to exit might dissuade some foreign issuers from accessing the U.S. capital markets as an initial proposition, the SEC proposed a substantial liberalization if its approach. Instead of the number of U.S. shareholders, the new approach looks to the relative U.S. market interest in the foreign company's securities. The key issue is whether the U.S. average daily trading volume does not exceed five percent of the worldwide amount. If so, and subject to the other requirements of the new rule, the issuer can terminate its obligation to file 1934 Act reports and take advantage of the $12 \mathrm{~g} 3-2$ (b) exemption. ${ }^{70}$ The resulting opportunity to walk away from the U.S. trading markets proved immediately popular for foreign companies. According to data compiled by the CCMR, the number of annual delistings from the NYSE, which had averaged 22.7 for the period 1997-2006, jumped to seventy-two in 2007, the year of the new rule's initial effectiveness. The rate has since returned to prior levels, however. ${ }^{71}$ The

69. See generally Edward Rock, Securities Regulation as Lobster Trap: A Credible Commitment Theory of Mandatory Disclosure, 23 CARDOzo L. REv. 675 (2002).

70. 17 C.F.R. $\S 240.12(\mathrm{~h})(6)(2009)$.

71. Committee on Capital Markets Regulation, Delistings by Foreign Companies from the New York Stock Exchange (2008) available at http://www.capmktsreg.org/competitiveness/ 2009Q2update/(9A) Delistings_by_Foreign_Companies_from_the_New_York_Stock_Exchange.pdf(last visited Feb. 16, 2010). 
overall trend is nonetheless clear. The number of foreign companies registered under the 1934 Act grew steadily and significantly throughout the 1990s, reaching a year-end peak of 1,344 in 2001 . Since then it has declined by roughly a quarter to the 2008 level of $1,024 .^{72}$

\section{Assessing the Future}

Globalization presents a formidable threat to the SEC's regulatory primacy. Throughout most of its history, U.S. securities law and regulatory philosophy has had the freedom to develop in relative isolation. Unrivaled in terms of their depth or breadth of investor participation, our public capital (especially equity capital) markets presented the SEC with not only unique regulatory challenges but also the leverage to address those challenges with the confidence that regulated parties lacked comparable opportunities elsewhere. What resulted, especially in the 1933 Act setting, was an expansive approach to investor protection. Consider, for example, the SEC's longstanding prohibition on any sort of publicity or other information (advertisements, press releases, speeches, etc.) that, even though removed from the formal securities distribution process, might nonetheless work to "condition the market" for an upcoming offering. ${ }^{73}$ Today, of course, the internet severely complicates any such endeavor to systematically regulate information flow, particularly when that information emanates from outside the United States.

At the same time, globalization has created viable competitive alternatives where none previously existed. Information and communications technology now allow both the bread and the butter of the securities business - capital and information - to be delivered from one part of the world to another with virtual immediacy. Besides the threat to the SEC's regulatory effectiveness, there also results a parallel threat to the various private actors regularly affected by U.S. securities regulation. U.S.-based issuers, financial services providers, and money managers increasingly compete, and are benchmarked, on a global basis. Do the strictures of U.S. securities regulation place them at a competitive disadvantage in relation to their foreign counterparts?

72. The data in the text are derived from the SEC's Annual Reports for the years before 2000, and for 2000-2008, from the SEC's annual compilation of "International Registered and Reporting Companies." This compilation is available at the SEC's official website. See Securities and Exchange Commission, International Registered and Reporting Companies, http://www.sec.gov/divisions/corpfin/ internatl/companies.shtml.

73. See generally 1 Loss ET AL., supra note 3, at 652-63 (4th ed. 2006). 
Thus we have the elements of the basic tension that has defined the SEC's approach to foreign private issuers over the last three-plus decades, and will no doubt continue to do so for the foreseeable future. On the one hand, the SEC must be alert to the continuing emergence of new opportunities, created by the globalized marketplace, to evade or undermine its established regulatory objectives. On the other, it must be sensitive to confront those opportunities in ways that do not unduly prejudice the competitive position of U.S.-based participants in that marketplace.

Sections II and III have provided several illustrations of the kinds of accommodations that have resulted, to date, from this fundamental tension. All too often, such accommodations made in recognition of one set of U.S. interests will impair those of another. While the title to this paper refers to the "balance" of those competing interests, "web" or "knot" may be a more vivid metaphor. Those metaphors, however, invoke the image of a static and immutable set of entitlements. "Balance" was therefore chosen instead, to reflect the importance of an equilibrium that, given the pace of globalization, is in need of constant readjustment.

This challenge of dynamic rebalancing will be the key to the SEC's role in the years ahead. To reflect on some of the issues embodied in this challenge, let us examine the separate perspectives of each of the U.S. groups having an important stake in the enterprise-issuers, investors and the financial services industry. ${ }^{74}$

\section{A. U.S. Issuers}

Consider the alternative approaches to regulatory jurisdiction and philosophy available to the SEC in the international arena. If given their choice, U.S. issuers would presumably prefer a strictly territorial approach - regulate transactions within the United States, ignore those abroad, whatever the nationality of the parties. These issuers are headquartered in the country that continues to feature both the deepest capital markets and the strictest securities regulation. Having been compelled to disclose all that is required by U.S. law, U.S. companies would likely prefer that the foreign companies that compete with them for capital in the U.S. marketplace be compelled to do the same. Likewise, when they go abroad, should not U.S. companies be free to raise capital on the same terms that apply to local firms?

74. For an alternative survey of the various groups with interests in the global securities marketplace, see Steven M. Davidoff, Regulating Listings in a Global Market, 86 N.C. L. REv. 89, 114-29 (2007). 
From a policy standpoint, such a purely territorial approach would afford issuers and investors greater freedom to choose the laws governing their offerings, and thereby promote a global competition among securities regulators. The costs and benefits of such an approach have been the subject of a lively scholarly debate. ${ }^{75}$

How does this theoretical perspective jibe with the U.S. experience to date? While a territorial approach has been the starting point, Sections II and III have catalogued numerous instances of nationality-based adjustments, all for the purpose of easing access for the foreign issuer. These are evident in each of the four transactional settings we surveyed: In registered public offerings, special disclosure requirements apply. For private offerings under Rule 144A, a mix of legal and practical considerations not available to domestic issuers make it far more attractive for foreign issuers to use the Rule to raise equity capital. These include the limitation of the fungibility concept to securities traded in the U.S. markets; the availability of the $12 \mathrm{~g} 3-2$ (b) exemption to avoid registration under the 1934 Act, and the opportunity for resales under Reg. S into the issuer's home trading market. When raising capital abroad, the greater risk of flow back means that for equity and convertible debt offerings, U.S. issuers will always be subject to offering restrictions and a distribution compliance period, ${ }^{76}$ and almost always so in the case of nonconvertible debt offerings. ${ }^{77}$ The 1998 amendments to Reg. S gave us a direct example of the SEC's attaching a higher priority to risk of abuse and flow back than to treating U.S. and foreign issuers (even foreign issuers whose principal securities market was the U.S.) alike. ${ }^{78}$ Finally, in the U.S. trading markets, foreign issuers are spared the obligation to report their financial results on a quarterly basis and to comply with U.S. proxy and shortswing profit rules. Further, the U.S. exchanges have also generally exempted foreign issuers from the corporate governance provisions of their listing standards. ${ }^{79}$

75. See generally Stephen J. Choi \& Andrew T. Guzman, Portable Reciprocity: Rethinking the International Reach of Securities Regulation, 71 S. CAL. L. Rev. 903 (1998); Merritt B. Fox, Retaining Mandatory Securities Disclosure: Why Issuer Choice Is Not Investor Empowerment, 85 VA. L. Rev. 1335 (1999); Roberta Romano, Empowering Investors: A Market Approach to Securities Regulation, 107 YALE L.J. 2359 (1998).

76. 17 C.F.R. $\S 230.903(b)(2),(3)(2009)$.

77. 17 C.F.R. $\S 903(b)(1)(i i)(B)(2009)$.

78. See Offshore Offers and Sales, Securities Act Release No. 7505 supra note 54, at 9633.

79. See, e.g., John C. Coffee, Jr., Racing towards the Top?: The Impact of Cross-Listings and Stock Market Competition on International Corporate Governance, 102 CoLum. L. REv. 1757, 1821-24 (2002). 
Consistent with our overall focus on the balance of competing interests, these accommodations have frequently been grounded on concern for the other two members of our tri-party equilibrium-U.S. investors and the financial service industry. ${ }^{80}$ Yet there is also a larger, multinational policy dimension that helps legitimize this particular balance. The concepts of mutual recognition and harmonization now occupy a much more visible and permanent place in the international dialogue over securities law reform. ${ }^{81}$ They also supply the basis for a pragmatic, ends-versus-means response to U.S. issuers and others who might question why the SEC's view of appropriate investor protection varies based on the nationality of the issuer: Conditional access to U.S. capital markets based on the level of home-country regulation provides an important incentive for foreign countries to improve their local laws, and thereby helps protect U.S. investors who deal directly in those markets.

For capital-raising activities outside the United States, there is a separate set of reasons why the SEC can be expected to treat U.S.-based issuers more rigorously than their foreign counterparts. We saw in the case of Release 4708 and Reg. S that the SEC retains a regulatory interest in protecting U.S. investors even when engaged in offshore transactions, and as a practical matter, those investors are more likely to deal on a regular basis in securities of home-country companies. Further, under principles of international law and comity, the case for extraterritorial application of U.S. law no doubt grows much stronger when both sides of an offshore transaction are U.S. persons.

Given this pervasive pattern of differential treatment, it is surprising that U.S. issuers have not been more vocal about being competitively disadvantaged. As we ponder the SEC's future, can this spirit of acceptance be expected to endure as U.S. companies finds themselves competing more regularly for capital in a unified global marketplace?

Complicating the answer is the prospect that while U.S.-based issuers may from time to time cite various components of the U.S. system as being unduly burdensome (class actions and Sarbanes-Oxley are the two most obvious candidates), the package as a whole may actually work to their net competitive advantage by lowering their cost of capital. Some have portrayed the comparative strictness of U.S. securities regulation as a source of

80. See, for example, the two passages from SEC releases quoted supra at notes 11,12 and 33 .

81. See, e.g., Margaret E. Tahyar et al., Securities, in Final Report of the Securities Law Subcommittee of the Task Force on Extraterritorial Jurisdiction at 266, 279-85 (Legal Practice Div. of the Int'1 Bar Ass'n 2008), available at $\mathrm{http}: / /$ papers.ssrn.com/sol3/papers.cfm?abstract_id=1109061 (last visited Feb. 16, 2010). 
opportunity for foreign companies to warrant the quality of their corporate governance by cross-listing on U.S. markets and thereby submitting themselves to SEC oversight. ${ }^{82}$ This view draws support from the empirical studies demonstrating the significant positive valuation effects enjoyed by foreign firms cross-listing on U.S. exchanges. ${ }^{83}$ Extending this logic, the SEC's various accommodations to foreign private issuers might actually work to their disadvantage by undermining their ability to reassure investors that they conform to the same high standards as their U.S. counterparts.

Advantage or disadvantage, what does the future portend? The SEC's most recent rulemaking on the subject suggests a move, at least in the case of disclosure requirements, to narrow the differential treatment between domestic and foreign private issuers. ${ }^{84}$ But we should expect, as with any dynamic equilibrium, some give and take. As foreign securities markets mature, become more fully integrated into the global financial environment and their regulators gain more experience, there will be the understandable offsetting tendencies to develop more confidence in the quality of home-country regulation while perceiving less need to tolerate departures from emerging international norms. Overall, absent a significant change in global sentiment, the long-term trend will almost certainly be in favor of greater harmonization in the treatment of issuers, ${ }^{85}$ and with it, away from the need for mutual recognition or other forms of deference to the local law of the issuer's domicile.

Harmonization, to be sure, raises important issues of national sovereignty. In particular, might it constrain Congress's political inclination to address domestic scandals through amendments to the federal securities laws, as it did with both the Foreign Corrupt Practices Act of $1977^{86}$ and Sarbanes-Oxley?

82. See, e.g., John C. Coffee, Jr., The Future as History: The Prospects for Global Convergence in Corporate Governance and Its Implications, 93 Nw. U. L. Rev. 641 (1999); René M. Stulz, Globalization, Corporate Finance, and the Cost of Capital, J. Applied Corp. Fin., Fall 1999, at 8.

83. See, e.g., Craig Doidge et al., Has New York Become Less Competitive than London in Global Markets? Evaluating Foreign Listing Choices over Time, 91 J. Fin. ECon. 253, 268-74 (2009); Luzi Hail \& Christian Leuz, Cost of Capital Effects and Changes in Growth Expectations around U.S. CrossListings, 93 J. Fin. ECON. 428 (2009).

84. Foreign Issuer Reporting Enhancements, Securities Act Release No. 8959, Exchange Act Release No. 58620, 73 Fed. Reg. 58300, 58301 (Sept. 23, 2008) ("[S]ome of the disclosure accommodations that we provided to foreign private issuers almost 30 years ago may no longer be appropriate or necessary in light of global market developments and advancements in technology").

85. See id. ("[T] here has been a movement toward greater international agreement on the accounting and other non-financial statement disclosures that should be provided by issuers. The Commission has undertaken a number of initiatives that recognize this.").

86. Pub. L. 95-213, 91 Stat. 1494 (1977). 
Conscious of the increasingly globalized marketplace, lawmakers should appreciate the Hobson's choice between, on the one hand, departing from the spirit of international cooperation by subjecting foreign companies to a uniquely U.S. policy prescription and, on the other, exempting those companies to the possible competitive disadvantage of their U.S. counterparts that likewise do business on a global basis.

\section{B. U.S. Investors}

Just as U.S. issuers might favor the flexibility and choice afforded by a purely territorial approach, investors who desire access to the widest array of international investment opportunities would favor an approach such as mutual recognition, which entrusts regulation to the issuer's home country and market, even in cross-border transactions. Of course, whether U.S. investors would in fact opt for this approach necessarily depends upon how much they value the protections of U.S. regulation.

Thus far, the SEC's response to the issue of investor choice in the face of globalization is to draw a sharp line between institutional and retail investors. While this segmentation is not confined to transactions in the securities of foreign issuers, ${ }^{87}$ it is especially well suited to the challenges of global investment. By employing the familiar "fend for themselves" rationale ${ }^{88}$ the SEC can assure U.S. institutions essentially the same access as their foreign competitors to new offerings from around the world and the ability to provide their (in most cases U.S.) clients with the full benefits of global diversification. Illustrations of this selective treatment of institutions in Section II include not only Rule 144A but also, more subtly, the ability to engage in offshore transactions through foreign agents and branches under Reg. S.

Section II described how this has produced a dramatic shift in the composition of the new issue market, away from 1933 Act registered offerings in favor of private placements under Rule 144A. It has had a comparable effect on the distribution of securities in the secondary markets, so that ordinary investors no longer have as convenient an opportunity to invest in, or access to SEC-mandated disclosure on, the majority of foreign companies trading in the U.S. markets. In a recent article, Doidge, Karolyi and Stulz report the breakdown in foreign equity listed on the U.S. exchanges versus

87. See infra note 90 and accompanying text.

88. SEC v. Ralston Purina Co., 346 U.S. 119, 125 (1953). 
traded in the over-the counter and 144A markets for the period 1990-2005. ${ }^{89}$ Exchange-listed issuers dropped from $68 \%$ to $42 \%$ of the total.

There is every reason to believe this trend away from 1933 and 1934 Act registration will continue. From a legal standpoint, Rule 144A seems to be working for foreign issuers exactly as the SEC had hoped. While room exists to adjust the definition of a QIB, most of the rule's other components (especially those of principal value to foreign equity issuers - fungibility and the linkage to Reg. S resales and the 12g3-2(b) exemption) are relatively cut and dried. Thus, neither the need not the ready mechanism exists for the kind of regulatory give and take that characterizes the disclosure requirements, as discussed in Subsection A above. From an economic standpoint, there is a growing body of scholarship indicating that firms seeking to raise capital and have their shares traded in foreign markets are less inclined than in years past to do so through listing on a U.S. exchange. We will examine the debate over the reasons for this phenomenon in the next Subsection. For present purposes, it is important to recognize that we are talking not simply about the effects of Sarbanes-Oxley or the availability of Rule 144A but also a shift in the kinds of firms that pursue cross-listings.

If this trend does persist, one likely casualty over time will be the SEC's role as global standard-setter on matters of disclosure content and format. This is the inevitable direct consequence of fewer foreign companies filing under the 1933 and 1934 Acts, and those that do being increasingly governed by more harmonized international standards. Yet the even more important consequence may be the indirect one. Technically, the fact that an offering is exempt from registration means that instead of the disclosures mandated by the SEC, the issuer and underwriters are free to tell investors as much or as little as they please, subject only to the antifraud rules. But the reality is very different. In offerings under Rule 144A the practice is to provide disclosure and supporting documentation closely resembling that required for a registered offering. ${ }^{90}$ This should hardly be surprising — professional investors are accustomed to seeing and evaluating certain kinds of information. And a common format facilitates comparisons between firms. Thus, the disclosure standards developed by the SEC in the registration context have spilled over

89. Doidge et al., supra note 83 , at 258 tbl.1.

90. See John C. Cocchiarella \& Robert S. Risoleo, Private Placements, Resales and Rule 144A and Regulation S Offerings, in Securities Offerings 2009: What Counsel Need to Know to Get Deals Done in Challenging Markets 921, 925, 1017 (PLI2009); Robert P. Bartlett III, Commentary, 51 Ariz. L. REv. 47, 52 n. 15 (2009). Jackson and Pan document this practice in the case of European offerings. See Jackson \& Pan, supra note 24, at 255-57. 
into the exempt offering market, and have no doubt played an important role in improving the level of disclosure and transparency globally. As new disclosure issues and challenges arise in the years ahead, can the SEC's disclosure requirements realistically be expected to exercise the same gravitational force in a world where, for foreign issuers, the 1933 Act registered offering is much more the exception than the rule?

The other important consequence is that a smaller share of foreign investment opportunities will be available to the ordinary investor through the U.S. trading markets. As a political or public relations matter, this may not have been as troublesome in an earlier time when investing in foreign companies still had an exotic aura and outside participation in many foreign markets was limited. That is clearly changing, with the changes posed to accelerate. ${ }^{91}$ Two messages from the recent financial crisis were not likely lost on most retail investors - the importance of diversification and the prediction that in future years, opportunities for significant and sustained investment growth will disproportionately be found in developing markets. The irony, therefore, is that just as the lure of global investing is reaching Main Street, Main Street finds its opportunities to act on it contracting.

Some will applaud this development, on the ground that unsophisticated investors have no business trying to pick individual winners among foreign stocks. ${ }^{92} \mathrm{We}$ are accustomed to many other types of investments (hedge funds, private equity and venture capital, for example) that are available only to institutions and other limited classes of issuers through offerings that qualify for exemption under the 1933 Act. ${ }^{93}$ Foreign stocks are fundamentally different, however, because they are already traded at the retail level, so that

91. As the "home bias" literature demonstrates, globalization has not eliminated the tendency of investors to overweight their portfolios in favor of local stocks. We can, however, expect home bias to diminish over time as the quality of governance in foreign capital markets improves and reduces the benefits of insider control. See Bong-Chan Kho et al., Financial Globalization, Governance, and the Evolution of the Home Bias, 47 J. ACCT. Res. 597 (2009).

92. The leading example of this view in the scholarly literature is Stephen Choi, Regulating Investors Not Issuers: A Market-Based Proposal, 88 CAL. L. Rev. 279, 300-02, 309 (2000) (advocating investor licensing through which unsophisticated investors would be limited to passive index funds). For a contrary view, see Davidoff, supra note 74 (advocating a "demand-side" approach that better takes into account the interests of U.S. retail investors).

93. More broadly still, there has been substantial recent attention to the overall "deretailization" of the investment markets and its implication for securities regulation and policy. See, e.g., Brian G. Cartwright, The Future of Securities Regulation, Speech at the University of Pennsylvania Law School Institute for Law and Economics (Oct. 24, 2007), http://www.sec.gov/news/speech/2007/ spch102407bgc.htm; Donald C. Langevoort, The SEC, Retail Investors, and the Institutionalization of the Securities Markets, 95 VA. L. REv. 1025 (2009). 
U.S. investors can track their price movements and usually obtain comprehensive English-language business and financial information prepared under standards set by a foreign regulator. This in turn leads to the most critical difference from a policy standpoint: Notwithstanding the lack of a U.S. trading market, U.S. investors can increasingly purchase these shares any way, either through their U.S. broker (who fills the order on the U.S. Level I ADR market or through a foreign branch or broker) or by establishing an account directly with a foreign broker. ${ }^{94}$ This is, admittedly, hardly a substitute for domestic trading. Not all foreign markets are accessible, and additional fees and expenses typically apply. Further, foreign brokers that routinely follow local stocks are reluctant to make their research available in the United States, lest they be charged with illegally soliciting orders..$^{95}$ Thus, the present state of affairs in the United States represents, at best, investor protection though inconvenience.

While the prior subsection discussed the debate over issuer choice, the more lasting consequence of globalization and the internet may be to force the SEC to philosophically grapple with the issue of investor choice as never before. One possible response is to maintain the present approach. As U.S. retail demand for foreign securities grows, U.S. broker-dealers may find it worthwhile to expand their services and compete more aggressively for this business. ${ }^{96}$ However, whether this would provide U.S. investors with anything approaching the level of research available from the local analysts in the issuer's home country or region is doubtful..$^{97}$ The alternative is to ease the current law to allow U.S. investors more direct access to foreign brokers and markets. This is where the dimensions of investor choice become central.

94. A Wall Street Journal columnist has authored a book advising retail investors about how to take advantage of these opportunities. JefF D. Opdyke, The World Is Your Oyster: The Guide to Finding Great InVestments Around the Globe (Crown Business 2008). There no doubt are or will be others.

95. 17 C.F.R. $\$ 240.15 a-6(a)(1)$ (2009); see Registration Requirements for Foreign Broker-Dealers, Exchange Act Release No. 27,017, 54 Fed. Reg. 30,013, 30,021-23 (July 18, 1989) (to be codified at 17 C.F.R. pt. 240).

96. It is always reassuring when fact confirms theory. The week after the symposium for which this paper was prepared, Fidelity announced an expansion of its online trading services to include stocks from 12 foreign markets. Jane J. Kim, Fidelity Pumps Up Foreign Trading, Wall St. J., Oct. 22, 2009, at D2. That same week, the firm also issued a newsletter for its clients entitled "Why Foreign Stocks are Important," emphasizing the importance of international diversification. See Fidelity Brokerage SeRvices LlC, Fidelity ViewPoints (Oct. 21, 2009) available at http://personal.fidelity.com/ products/publications.

97. The SEC permits a US broker to distribute research prepared by a foreign broker so long as it expressly accepts responsibility for the content. See Registration Requirements for Foreign Broker-Dealers, 54 Fed. Reg. at 30,023. 
Should unregistered foreign brokers be given greater latitude to solicit business from U.S. investors? Those investors already have some ability to opt out of the SEC's protections by placing an unsolicited order abroad. Under what circumstances should the SEC now permit the foreign broker to solicit that order within the United States?

Neither of the two answers to that question that have been proposed to date is likely to satisfy most ordinary investors interested in actively buying and selling foreign stocks. One is to amend Rule 15a-6 to expand the pool of investors with whom a foreign broker can transact business without being required to register with the SEC..$^{98}$ Individuals would now be eligible, but only if they have $\$ 25$ million or more in personal investments. ${ }^{99}$ Thus, segmentation of investors continues to be an important ingredient of SEC policy toward foreign private issuers, though as a result of globalization, the line of demarcation is shifting. The other proposal, first suggested by SEC staff members, is a variation on mutual recognition, motivated in part by the plight of the retail investor seeking greater access to global markets. ${ }^{100}$ Termed "substituted compliance," the proposal would allow foreign stock exchanges and broker-dealers to provide service within the United States "based on their compliance with substantively comparable foreign securities regulations and laws and supervision by a foreign securities regulator with oversight powers and a regulatory and enforcement philosophy substantively similar to the SEC's." ${ }^{\prime 01}$ In the wake of the proposal, the SEC announced a series of contemplated initiatives to implement the mutual recognition for "high-quality regulatory regimes in other countries." 102 While this may well lead to more available investment opportunities in the United Kingdom, Australia, Canada, Japan, and Western Europe, it will add little in the areas of the world likely of most interest to U.S. retail investors seeking diversification and growth in the years ahead-developing and recently developed countries.

The specifics of an approach - one that enables greater investor access to emerging markets - are beyond the scope of the paper, but consider three

98. Exemption of Certain Foreign Brokers or Dealers, Exchange Act Release No. 58,047, 73 Fed. Reg. 39,182 (July 8, 2008) (to be codified at 17 C.F.R. pt. 240).

99. Exemption of Certain Foreign Brokers or Dealers, 73 Fed. Reg. at 39,185-86; see 15 U.S.C. $\S 78 \mathrm{c}(\mathrm{a})(54)(\mathrm{A})(\mathrm{xii})$ (2006) (definition of "qualified investor").

100. Ethiopis Tafara \& Robert J. Peterson, A Blueprint for Cross-Border Access to U.S. Investors: A New International Framework, 48 HARV. INT'L L.J. 31, 41-42 (2007).

101. Id. at 32 .

102. Press Release, United States Sec. \& Exch. Comm'n, SEC Announces Next Steps for Implementation of Mutual Recognition Concept (Mar. 24, 2008) (on file with author), available at http://www.sec.gov/news/press/2008/2008-49.htm. 
possible elements. First, enhanced access should be limited to the securities of issuers whose market capitalization and free float exceed a prescribed threshold - those about whom the greatest amount of public information is likely to be available - and meet other governance-related criteria. Second, as to those issuers, the approach should facilitate the distribution and availability of research prepared by the well-established banks and brokerage houses in the issuer's region. Finally, and especially in smaller markets, the approach could encourage and take advantage of opportunities for regional alliances of regulators and stock exchanges to establish eligibility criteria for a category of world-class issuers (those of most interest to foreign investors) that go beyond the listing standards of the individual member countries. ${ }^{103}$ Collectively, these elements address a major limitation in the mutual recognition proposals advanced to date. By testing for substantive similarity at the exchange or regulator level, these proposals necessarily exclude, country by country, the few well-established issuers that might trade locally on a market that is not otherwise deep. The resulting incentive for these companies to cross-list in a more SEC-like regulatory environment is likely to divert substantial volume from the home market and impede its long-term development.

\section{U.S. Financial Services Industry}

Although at the center of the pre-crisis focus on the competitiveness of U.S. capital markets, the set of interests considered in this subsection are much more challenging to translate into concrete policy choices facing the SEC, than was the case with U.S. issuers and investors. One major source of that uncertainty is, of course, the current political climate. For the foreseeable future, it is difficult to imagine either the SEC or Congress being responsive to the concerns of the firms whose greed and self-interest many blame for the current crisis, and which were the principal beneficiaries of the bailout. The industry's case is hardly strengthened by the fact that in the period of most concern from a competitiveness standpoint - the years following Sarbanes-

103. Examples include the opportunities presented by the recently created ASEAN Common Exchange Gateway alliance in Southeast Asia. See Kevin Brown, Boost for Asean Bulletin Board Scheme as Vietnam Signs Up, Fin. Times, Sept. 16, 2009, at 39. For a more general recognition of the role that regional oversight might play, see Howell E. Jackson, Toward a New Regulatory Paradigm for the TransAtlantic Financial Market and Beyond: Legal and Economic Perspectives, 10 Eur. BuS. ORG. L. Rev. (forthcoming 2010). 
Oxley-profits for the financial sector as a whole grew to unprecedented levels. ${ }^{104}$

Public opinion aside, there is also the fundamental challenge of assessing the causal connection between the kinds of regulatory issues we have been considering and the industry's overall competitive position. All major U.S.based providers of capital and services (investment and commercial banks, law and accounting firms, etc.) now compete on a global basis. Even if U.S. regulation drives new foreign offerings and listings abroad, aren't the foreign offices of these U.S. firms well positioned to pursue that business? ${ }^{105}$ Indeed, this is the place where the specific interests of the U.S. financial industry loom most visibly in the various proposed reforms discussed above-access to foreign markets. This explains the importance of reciprocity as a condition for allowing foreign securities firms access to the U.S. capital markets on the basis of their local regulation. ${ }^{106}$ As the debate on these proposals continues, it will make for an interesting horse trade-more flexible U.S. investor protection in return for more open foreign markets. ${ }^{107}$

Finally, there is the issue at the heart of the causation inquiry: have U.S. regulation in fact caused our capital markets to become less competitive? This has been the subject of substantial recent attention in the scholarly literature, with two principal groups of studies pointing in different directions. One group considers the stock market reaction to the enactment of Sarbanes-Oxley and finds that the stock prices of those foreign companies listed in the United

104. According to the Commerce Department's National Accounts data, from 1929 through 1988, financial sector profits averaged 1.2\% of Gross Domestic Product and never exceeded 1.7\%. By 2005, they had reached 3.3\%. See Floyd Norris, To Rein In Pay, Rein In Wall St., N.Y. Times, Oct. 30, 2009, at B1. In the four years preceding Sarbanes-Oxley, those profits averaged $\$ 203$ billion annually (2.1\% of GDP), compared to $\$ 384$ billion (3.1\% of GDP) in the four years following enactment. See BurEau Econ. Analysis, Nat'L Income \& Products Accounts Table, Table 6.16D. Corp. Profits by Indus. (2009), available at $\mathrm{http}: / / \mathrm{www} \cdot$ bea.gov/national/nipaweb/index.asp.

105. The only data reported by the CCMR on the industry-specific impact of diminished U.S. market competitiveness were the revenues from underwriting and M\&A advisory work, broken down by nationality of the client. From 1996 through the second quarter of 2009, work on behalf of U.S. clients fell from $52 \%$ to $39 \%$ of the total. Comm. on Capital Mkts. Regulation, M\&A Advisory \& Equity/Debt Capital Mkt. Underwriting Revenue by Client-Parent Nationality (2009), available at http:// www.capmktsreg.org/competitiveness/2009Q2update/(13)MA_Advisory_and_Equity_Debt\%20Capital _Market_Underwriting_Revenue_by_Client_Nationality.pdf. The CCMR acknowledges, however, that this has no direct impact on the US competitive position, but has likely contributed to a shift of investment bank personnel from the US to abroad. Committee on CAPital Mkts. Regulation, supra note 1, at 29.

106. See Tafara \& Peterson, supra note 100, at 61-62.

107. Cf. Howell E. Jackson et al., Foreign Trading Screens in the United States, 1 CAPITAL Markets L.J. 54, 56-69 (2006) (describing the difference between U.S. and European views on this trade-off, as applied to foreign trading screens). 
States and subject to SEC regulation declined relative to comparable firms. ${ }^{108}$ This suggests that investors in those companies viewed the Act's burdens as exceeding its benefits, particularly for those headquartered in countries with stronger local investor protection, where the adverse market reaction tended to be greater. Somewhat conversely, several other studies find that the valuation premium that results from listing on a U.S. exchange remains substantial and has not been significantly affected by Sarbanes-Oxley. ${ }^{109}$ Further complicating the picture are the studies analyzing the market's reaction to foreign firms' decisions to delist and deregister, which report mixed results as to Sarbanes-Oxley effects. ${ }^{110}$

The challenge for all these studies is isolating the effects of the specific event being evaluated (the enactment of Sarbanes-Oxley, listing, delisting, etc.) from the many market-affecting circumstances that might accompany that event. Thus, we can expect further rounds of studies taking different approaches and controlling for different alternative explanations. Those recent studies that have attempted to subdivide the listing premium into its multiple possible causes have found that a least some of the increase can be attributed to the greater protection afforded by U.S. regulation. ${ }^{111}$

Given these continuing benefits of a U.S. listing, why the recent fall-off in those listings and accompanying increase in delistings? Two plausible answers have emerged. One is that the listing decision is made by management or controlling shareholders whose interests are not necessarily the same as the

108. Xi Li, The Sarbanes-Oxley Act and Cross-Listed Foreign Private Issuers (Jan. 18, 2007) (unpublished working paper, available at http://ssrn.com/abstract=952433); Kate Litvak, The Effect of the Sarbanes-Oxley Act on Non-US Companies Cross-Listed in the U.S., 13 J. CorP. FIN. 195 (2007); Kate Litvak, Sarbanes-Oxley and the Cross-Listing Premium, 105 Mich. L. Rev. 1857 (2007); Geoffrey Peter Smith, What Are the Effects of Sarbanes-Oxley on Cross-Listed Companies? (May 23, 2008) (unpublished working paper, available at http://ssrn.com/abstract=931051).

109. Doidge et al., supra note 83, at 269-72 (showing an insignificant decrease in premium); Jefferson Duarte et al., The Impact of the Sarbanes-Oxley Act on Shareholders and Managers 24 (Aug. 10, 2009) (showing a significant positive post-SOX effect) (unpublished working paper, available at http://ssrn.com/abstract=1062641); Hail \& Leuz, supra note 83, at 439-40 (cost of capital reductions not attenuated after SOX). But see Luigi Zingales, Is the U.S. Capital Market Losing its Competitive Edge? 11-14 (Univ. of Chi. European Corp. Governance Inst., Paper No. 192, 2007), available at http:// ssrn.com/abstract $=1028701$ (reinterpreting Doidge et al. data).

110. Compare Peter Hostak et al., An Examination of the Impact of the Sarbanes-Oxley Act on the Attractiveness of US Capital Markets for Foreign Firms 29 (Oct. 11, 2009) (demonstrating a significant negative reaction post-Sarbanes-Oxley) (unpublished working paper, available at http://ssrn.com/ abstract=956020) with Li, supra note 108, at 24-27; Andras Marosi \& Nadia Massoud, "You Can Enter but You Cannot Leave. .. ”: U.S. Securities Markets and Foreign Firms, 63 J. FIN. 2477, 2496-99 (2008) (demonstrating a reduced negative reaction after Sarbanes-Oxley).

111. Arturo Bris et al., A Breakdown of the Valuation Effects of International Cross-Listing, 13 EuR. Fin. Mgmt. 498, 518-21 (2007); Hail \& Leuz, supra note 83, at 447-48. 
minority shareholders. ${ }^{112}$ A comprehensive recent study documents that foreign companies with control arrangements that facilitate insider selfenrichment are less likely to cross list on U.S. exchanges. ${ }^{113}$ Thus, companies from countries with weaker corporate governance and more concentrated insider control, whose shareholders might therefore stand to benefit the most from Sarbanes-Oxley's enhanced protection, are for that very reason less inclined to cross-list on U.S. exchanges. ${ }^{114}$ That leads to the second possible explanation - that the nature of foreign firms interested in alternative securities markets may be changing. In response to the competitiveness debate, two recent studies examine foreign firms choosing between listing in the United States and the only other market to attract significant foreign listings, London. Based on the characteristics of firms that opted for New York over London before Sarbanes-Oxley, both studies found that postSarbanes-Oxley changes in the profile of listing firms would by itself explain a significant decline in U.S. exchange listings. ${ }^{115}$

The New York versus London comparisons also reveal that the one trading market that has attracted a substantial number of firms that might have previously listed in the U.S. is London's Alternative Investment Market (AIM). These tend to be small and less profitable companies, and less likely to employ one of the Big Four accounting firms as their auditor. ${ }^{116}$ Their

112. See, e.g., John C. Coffee, Jr., Law and the Market: The Impact of Enforcement, 156 U. PA. L. REv. 229, 286-88 (2007).

113. Craig Doidge et al., Private Benefits of Control, Ownership, and the Cross-Listing Decision, 69 J. FIN. 425 (2009).

114. This is the one aspect of the competitiveness debate that appears to find universal support in the empirical work. See, e.g., Doidge et al., supra note 83, at 262-66 (showing that firms from less-developed countries and greater inside ownership more likely to use alternatives to U.S. exchange listing); Duarte et al., supra note 109, at 17, 22-26 (demonstrating that firms from countries with weaker governance less likely to list, but those that do generate greater post-Sarbanes-Oxley listing premiums); Hail \& Leuz, supra note 83 , at 445-47 (showing listing reduces cost of capital more for issuers from countries with weaker investor protection); Hostak et al., supra note 110, at 24 (demonstrating post-Sarbanes-Oxley deregistering firms characterized by more concentrated ownership); Marosi \& Massoud, supra note 110, at 2493 (demonstrating stronger shareholder protection reduces probability of deregistration; greater insider control increases it); Joseph D. Piotroski \& Suraj Srinivasan, Regulation and Bonding: The Sarbanes-Oxley Act and the Flow of International Listings, 46 J. AcCT. Res. 383, 404-06 (2008) (showing firms with weaker governance less likely to list on United States versus United Kingdom exchange); Zingales, supra note 109, at 11-14 (showing companies from countries with weaker protection incurred less decrease in listing premiums due to Sarbanes-Oxley).

115. The two studies differ, however, in their assessments of how the actual number of US listings compared with the prediction. Doidge et al., supra note 83, at 264-68 (demonstrating US exchange listings exceeded predicted levels); Piotroski \& Srinivasan, supra note 114, at 414 (showing U.S. exchange listings lower than expected).

116. Piotroski \& Srinivasan, supra note 114 , at $414-16$. 
preference for AIM is consistent with the frequently voiced concern that the compliance costs of Sarbanes-Oxley are particularly burdensome for smaller firms, and the results of a recent SEC survey indicating that section 404 of the Act has caused $46 \%$ of the small foreign firm respondents to very seriously consider delisting from U.S. exchanges. ${ }^{117}$ Coupled with AIM's dramatic success, this presents Congress and the SEC with a difficult choice that the Commission has thus far dealt with through deferral - whether to reserve U.S. listing for those foreign firms willing and capable of complete compliance with Sarbanes-Oxley, including section 404, or to exempt smaller firms in the hope of maintaining existing listings and encouraging new ones. [Recent House Adler amendment indicates a preference for the latter. Update]

\section{CONCLUSION}

The first part of this paper sought to trace the development of the SEC's regulatory approach to foreign private issuers, and how that regulation has both responded, and contributed, to shifts in financing patterns as capital markets have evolved from local to global over the last three-plus decades. The second part looked to the future in an effort to identify some of the more important challenges that globalization might create for the SEC. These include the SEC's continuing ability to shape global disclosure content and format in light of the declining importance of 1933 and 1934 Act registration, and how to meet the ordinary investor's increasing desire for access to emerging markets.

The phrase "grain of salt" has been applied to many efforts to predict the future, but it is particularly apt in the case of securities law. The process of accommodating U.S. regulation to the evolution of global capital markets has predominantly consisted of advocacy and technical fine-tuning at the behest of lawyers and other representatives of the various interests surveyed in Section IV. Major securities regulation reform, in contrast, tends to be the product of public outrage over scandal or crisis. One can imagine very different regulatory futures depending on whether the next Enron and WorldCom involve issuers (domestic or foreign) that are registered under the 1933 and 1934 Acts versus foreign issuers that have taken pains to avoid the SEC's regulatory jurisdiction.

117. Office of Econ. Analysis, U.S. Sec. \& Exch. Comm'n, Study of the Sarbanes-Oxley Act of 2002 Section 404 Internal Control over Financial Reporting ReQuirements 66-67 (2009), available at http://www.sec.gov/news/studies/2009/sox-404_study.pdf. 